\title{
MEKANISME PEMBERHENTIAN PRESIDEN DALAM SISTEM PEMERINTAHAN PRESIDENSIAL DI INDONESIA (Tinjauan Perbandingan Hukum di Negara Amerika Serikat, Filipina dan Sudan)
}

Oleh :

Dewi Mulyanti, S.H., M.H. $\left.{ }^{*}\right)$

dewimulyantiunigal@gmail.com

\begin{abstract}
The mechanism for the dismissal of the President in a term of office in the amendment to the Constitution of the Republic of Indonesia in 1945 is regulated in Article 3 paragraph (3), Article 7A, Article $7 B$ and Article 24C paragraph (2) of the 1945 Constitution of the Republic of Indonesia involving three State institutions, namely the House of Representatives, the Constitutional Court and the People's Consultative Assembly. The House of Representatives submitted an opinion to the Constitutional Court that the President violated the law, then the Constitutional Court examined the veracity of the opinion in a juridical manner and the results of the examination were returned to the DPR which subsequently submitted to the MPR to dismiss the President through the Plenary Session.
\end{abstract}

Keywords: Dismissal of the President, Indonesian Presidential Government System

\begin{abstract}
ABSTRAK
Mekanisme pemberhentian Presiden dalam masa jabatan pada perubahan Undang-Undang Dasar Negara Republik Indonesia Tahun 1945 secara normatif diatur dalam Pasal 3 ayat (3), Pasal 7A, Pasal 7B dan Pasal 24C ayat (2) UndangUndang Dasar Republik Indonesia Tahun 1945 dengan melibatkan tiga lembaga negara yaitu Dewan Perwakilan Rakyat, Mahkamah Konstitusi dan Majelis Permusyawaratan Rakyat. Dewan Perwakilan Rakyat mengajukan pendapat kepada Mahkamah Konstitusi bahwa Presiden melakukan pelanggaran hukum, kemudian Mahkamah Konstitusi memeriksa kebenaran pendapat tersebut secara yuridis dan hasil pemeriksaan tersebut dikembalikan kepada DPR yang selanjutnya mengajukan kepada MPR untuk memberhentikan Presiden melalui Sidang Paripurna.

Kata Kunci: Pemberhentian Presiden, Sistem Pemerintahan Presidensial Indonesia

\section{PENDAHULUAN}

Salah satu agenda penting dan mendasar dari reformasi hukum adalah perubahan naskah Undang-Undang Dasar Republik Indonesia Tahun 1945. Hasilnya telah membawa perubahan fundamental terhadap sistem

*) Dosen Tetap Fakultas Hukum Universitas Galuh
\end{abstract}


ketatanegaraan Republik Indonesia, terutama berkaitan dengan pengaturan alasan dan tatacara pemberhentian Presiden dalam masa jabatan.

Hal yang secara teoritis merupakan konsekuensi logis dari adanya kemauan politik (political will) untuk mempertegas sistem pemerintahan presidensial yang merupakan salah satu kesepakatan dasar Panitia Ad Hoc I Badan Pekerja Majelis Permusyawaratan Rakyat (MPR). Penegasan system pemerintahan presidensial mensyaratkan adanya lembaga kepresidenan yang mempunyai legitimasi yang kuat dengan bercirikan antara lain adanya masa jabatan Presiden yang bersifat tetap (fixed term), Presiden disamping sebagai Kepala Negara sekaligus Kepala Pemerintahan, adanya mekanisme saling mengawasi dan saling mengimbangi (checks and balances) dan adanya mekanisme impeachment. Selain sebagai konsekuensi logis dari dianutnya system pemerintahan presidensial, pengaturan tentang pemberhentian Presiden dalam masa jabatan juga merupakan konsekuensi dianutnya ajaran pemisahan kekuasaan dengan mekanisme checks and balances system dalam perubahan Undang-Undang Dasar Republik Indonesia Tahunn 1945 (Zoelva, $2005 ; 65)$.

Dalam sejarah ketatanegaraan Republik Indonesia, tercatat telah empat kali terjadi Presiden berhenti sebelum masa jabatan berakhir, yaitu : Pertama, Presiden Soekarno diberhentikan melalui Ketetapan MPRS Nomor XXXIII/MPRS/1967 tentang Pencabutan Kekuasaan Pemerintahan Negara Presiden Soekarno; Kedua, Presiden Soeharto 'berhenti' setelah Ketua MPR/DPR mengumumkan permintaan MPR, agar Soeharto mengundurkan diri menyusul desakan demonstrasi mahasiswa dan elemen masyarakat lainnya pada tanggal 21 Mei 1998; Ketiga, Presiden B.J. Habibie berhenti setelah MPR menolak pertanggungjawaban pada Sidang Istimewa MPR tahun 1999, dan keempat, Presiden K.H. Abdurrahman Wahid diberhentikan oleh MPR melalui Ketetapan MPR Nomor II/MPR/2001 tentang Pertanggungjawaban Presiden Republik Indonesia K.H. Abdurrahman Wahid, karena tidak hadir dan menolak memberikan pertanggungjawaban dalam sidang istimewa MPR tahun 2001, dinilai terlibat dalam kasus penyelewengan dana bulog (Bulogate) dan dana bantuan dari Sultan Brunei Darussalam (Bruneigate) serta menerbitkan Maklumat Presiden RI tanggal 23 Juli Tahun 2001 (Nazriyah, 2007 : 165-166). 
Berdasarkan pengalaman praktik pemberhentian Presiden Indonesia di atas, diketahui bahwa pemberhentian Presiden dalam masa jabatan sebelum perubahan Undang-Undang Dasar Republik Indonesia Tahun 1945 lebih didasarkan pada pertimbangan politik, karena tidak melibatkan lembaga peradilan untuk menguji secara yuridis kebenaran atas perbuatan yang dituduhkan tersebut.

Dalam konteks Negara berdasarkan atas hukum, baik rechtsstaat, rule of law maupun Negara hukum Pancasila, pemberhentian Presiden seharusnya dapat dipertanggungjawabkan secara yuridis konstitusional yang melibatkan lembaga peradilan yang merdeka dan tidak memihak (independent and impartial tribunal), guna membuktikan secara yuridis kebenaran atas perbuatan yang dituduhkan kepada Presiden (Hufron, 2018; 4-5).

Berkaitan dengan tata cara atau mekanisme Pemberhentian Presiden dalam masa jabatan, pada Perubahan Ketiga Undang-Undang Dasar Republik Indonesia Tahun 1945 diatur dalam Pasal 7B Undang-Undang Dasar Republik Indonesia Tahun 1945 dan Pasal $24 \mathrm{C}$ ayat (1) dan (2) sebagai berikut :

Pasal 7B berbunyi :

(1) Usul Pemberhentian Presiden dan/atau Wakil Presiden dapat diajukan oleh DPR kepada MPR hanya dengan terlebih dahulu mengajukan permintaan kepada Mahkamah Konstitusi untuk memeriksa, mengadili dan memutus pendapat DPR bahwa Presiden dan/atau Wakil Presiden telah melakukan pelanggaran hukum berupa pengkhianatan terhadap Negara, korupsi, penyuapan, tindak pidana berat lainnya, atau perbuatan tercela dan/atau pendapat bahwa Presiden dan/atau Wakil Presiden tidak lagi memenuhi syarat sebagai Presiden dan/atau Wakil Presiden;

(2) Pendapat DPR bahwa Presiden dan/atau Wakil Presiden telah melakukan pelanggaran hukum tersebut ataupun telah tidak lagi memenuhi syarat sebagai Presiden dan/atau Wakil Presiden adalah dalam rangka pelaksanaan fungsi pengawasan DPR;

(3) Mengajukan permintaan DPR kepada Mahkamah Konstitusi hanya dapat dilakukan dengan dukungan sekurang - kurangnya 2/3 dari jumlah anggota DPR yang hadir dalam siding paripurna yang dihadiri oleh sekurangkurangnya $2 / 3$ dari jumlah anggota DPR; 
(4) Mahkamah Konstitusi wajib memeriksa, mengadili dan memutus dengan seadil-adilnya terhadap pendapat DPR tersebut paling lama sembilan puluh hari setelah permintaan DPR itu diterima oleh Mahkamah Konstitusi;

(5) Apabila Mahkamah Konstitusi memutuskan bahwa Presiden dan/atau Wakil Presiden terbukti melakukan pelanggaran hukum berupa pengkhianatan terhadap Negara, korupsi, penyuapan, tindak pidana berat lainnya atau perbuatan tercela dan/atau terbukti bahwa Presiden dan/atau Wakil Presiden tidak lagi memenuhi syarat sebagai Presiden dan/atau Wakil Presiden, DPR menyelenggarakan sidang paripurna untuk meneruskan usul pemberhentian Presiden dan/atau Wakil Presiden kepada MPR.

(6) Majelis Permusyawaratan Rakyat wajib menyelenggarakan sidang untuk memutuskan usul DPR tersebut paling lambat tiga puluh hari sejak MPR menerima usul tersebut;

(7) Keputusan MPR atas usul pemberhentian Presiden dan/atau Wakil Presiden harus diambil dapat rapat paripurna MPR yang dihadiri sekurang-kurangnya $3 / 4$ dari jumlah anggota dan disetujui sekurang-kurangnya 2/3 dari jumlah anggota yang hadir, setelah Presiden dan/atau Wakil Presiden diberi kesempatan menyampaikan penjelasan dalam rapat paripurna MPR.

Dari analisis mengenai tata cara pemberhentian Presiden dalam masa jabatan sebagaimana diatur dalam ketentuan Pasal 7B di atas, dikemukakan suatu kelemahan yuridis, yaitu tidak adanya batas waktu berapa lama DPR harus mengadakan Sidang Paripurna untuk meneruskan usul pemberhentian Presiden kepada MPR, setelah Mahkamah Konstitusi memutuskan bahwa Presiden terbukti melakukan pelanggaran hukum, dan/atau terbukti tidak lagi memenuhi syarat sebagai Presiden. Berapa lama waktu yang diperlukan untuk Sidang Paripurna DPR dalam rangka meneruskan usul pemberhentian Presiden kepada MPR ?

Mengingat tidak adanya limitasi atau pembatasan waktu sebagaimana dikemukakan di atas, maka DPR dapat saja mengulur-ulur waktu untuk tidak mengadakan Sidang Paripurna guna meneruskan usul pemberhentian Presiden, atau sebaliknya mempercepat pelaksanaan Sidang Paripurna tersebut. Sehingga pelaksanaan Sidang Paripurna sangat bergantung kepada kehendak atau kepentingan suara mayoritas anggota DPR. Dengan demikian, secara yuridis, tidak ada kepastian hukum 'perihal batas waktu' 
penyelenggaraan Sidang Paripurna DPR untuk meneruskan usul pemberhentian Presiden kepada MPR.

Jika terjadi dugaan pelanggaran, Mahkamah Konstitusi memiliki kewajiban yaitu memberikan putusan atas pendapat DPR mengenai dugaan pelanggaran hukum oleh Presiden. Akan tetapi, dalam hal MK menjalankan kewajiban untuk memberikan putusan atas Pendapat DPR mengenai dugaan pelanggaran oleh Presiden menurut Undang-Undang Dasar Republik Indonesia Tahun 1945, tidak disebutkan atau dijelaskan apakah gradasi pemeriksaan merupakan tingkat pertama sekaligus yang terakhir dan apakah juga putusannya bersifat final atau tidak?

\section{PEMBAHASAN}

\subsection{Mekanisme Pemberhentian Presiden Dalam Sistem Pemerintahan Presidensial}

\section{Beberapa Pengertian Dasar Terkait Pemberhentian Presiden}

Istilah 'pemberhentian' menurut Kamur Besar Bahasa Indonesia memiliki makna memecat atau melepas dari jabatan atau pekerjaan. Istilah 'pemakzulan', berasal dari kata 'makzul' yang memiliki arti berhenti dari memegang jabatan atau turun tahta. Memakzulkan berarti menurunkan dari tahta, memberhentikan dari jabatan. Dengan demikian pemakzulan Presiden/Wakil Presiden sama artinya dengan pemberhentian Presiden/Wakil Presiden dalam masa jabatan. Dalam terminologi hukum dan politik asing, istilah pemakzulan biasa disinonimkan dengan istilah Impeachment. 'Impeachment' berasal dari kata kerja to impeach artinya memanggil atau mendakwa untuk meminta pertanggungjawaban. Dalam hubungan dengan kedudukan Kepala Negara atau Pemerintahan, Impeachment berarti pemanggilan atau pendakwaan untuk meminta pertanggungjawaban atas persangkaan pelanggaran hukum yang dilakukannya dalam masa jabatan. Jika tuntutannya terbukti, maka hukumannya adalah removal from office (pemberhentian dari jabatan). Dalam konteks ini Impeachment diartikan sebagai proses pendakwaan Presiden/Wakil Presiden di hadapan Parlemen atas dugaan pelanggaran hukum yang dilakukan dalam masa jabatan (Sumbu, 2010 ; 252). 
Dalam hukum tata negara, terdapat tiga model pemberhentian Presiden sebelum masa jabatan berakhir yaitu forum privilegiatum, Impeachment, dan proses parlementer biasa karena mosi tidak percaya terhadap Presiden. Forum privilegiatum adalah model pemberhentian pejabat tinggi Negara, termasuk Presiden melalui mekanisme peradilan khusus (special legal proceeding) artinya Presiden yang dianggap melanggar hukum diberhentikan melalui mekanisme pengadilan dipercepat tanpa melalui jenjang pemeriksaan pengadilan konvensional dari tingkat bawah. Pemeriksaannya bersifat tingkat pertama dan tingkat terakhir dan putusannya bersifat final.

Model Pemberhentian Presiden Indonesia menganut sistem campuran antara model Impeachment dan model forum priveligiatum yaitu proses penjatuhan Presiden dimulai dari penilaian dan keputusan politik di DPR RI (impeachment) kemudian dilanjutkan ke pemeriksaan dan putusan hukum oleh Mahkamah Konstitusi (forum priveligiatum) lalu dikembalikan lagi ke prosedur impeachment (DPR meneruskan ke MPR) untuk diputuskan secara politik apakah putusan Mahkamah Konstitusi itu perlu ditindaklanjuti dengan pemberhentian Presiden ataukah tidak (Mahfud, $2007 ; 139$ ).

\section{Sistem Pemerintahan Presidensial (Presidential System)}

Sistem pemerintahan presidensial adalah sistem pemerintahan yang terpusat pada jabatan presiden sebagai kepala pemerintahan (head of government) sekaligus sebagai kepala Negara (head of state). Dalam sistem pemerintahan presidensial tidak dipisahkan antara jabatan Presiden sebagai kepala Negara (head of state) dan kepala pemerintahan (head of government).

Ada beberapa prinsip pokok yang bersifat universal dari karakteristik sistem pemerintahan presidensial adalah :

1. Terdapat pemisahan yang jelas antara cabang kekuasaan eksekutif dan legislatif;

2. Presiden merupakan eksekutif tunggal. Kekuasaan eksekutif presiden tidak terbagi dan yang ada hanya presiden dan wakil presiden; 
3. Kepala pemerintahan adalah sekaligus kepala Negara atau sebaliknya, kepala negara adalah sekaligus merupakan kepala pemerintahan;

4. Presiden mengangkat para menteri sebagai pembantu atau sebagai bawahan yang bertanggung jawab kepadanya;

5. Anggota parlemen tidak boleh menduduki jabatan eksekutif dan demikian pula sebaliknya;

6. Presiden tidak dapat membubarkan atau memaksa parlemen;

7. Jika dalam sistem parlementer berlaku prinsip supremasi parlemen, maka dalam sistem presidensial berlaku prinsip supremasi konstitusi. Karena itu pemerintahan eksekutif bertanggungjawab kepada konstitusi;

8. Eksekutif bertanggung jawab langsung kepada rakyat yang berdaulat;

9. Kekuasaan tersebar secara tidak terpusat seperti dalam sistem parlementer yang terpusat pada parlemen (Asshiddiqie, 2008 ; 316).

Selama empat kali perubahan Undang-Undang Dasar Republik Indonesia Tahun 1945 (1999-2002), pemurnian sistem pemerintahan presidensial dilakukan dalam bentuk : (i) mengubah proses pemilihan Presiden/Wakil Presiden dan pemilihan dengan sistem perwakilan (mekanisme pemilihan di MPR) menjadi pemilihan secara langsung; (ii) membatasi periodisasi masa jabatan Presiden/Wakil Presiden; (iii) memperjelas mekanisme pemakzulan (impeachment) Presiden/Wakil Presiden; (iv) larangan bagi presiden untuk membubarkan DPR; (v) memperbarui atau menata ulang eksistensi MPR; dan (vi) melembagakan mekanisme pengujian undang-undang (judicial review).

Salah satu upaya pemurnian sistem pemerintahan presidensial pasca perubahan Undang-Undang Dasar Republik Indonesia Tahun 1945 adalah memperjelas syarat dan mekanisme pemberhentian Presiden di tengah masa jabatan. Meskipun masa jabatan yang tetap ( fix term) adalah salah satu karakter utama sistem pemerintahan presidensial, tidak berarti presiden tidak bisa 
diberhentikan di dalam masa jabatannya. Dalam teori hukum tata negara (constitutional law theory), pemberhentian presiden di tengah masa jabatannya disebut impeachment (pemakzulan) yang secara hukum merupakan a legal process of removing an undersirable person from public office (Isra, $2010 ; 63$ ). Tindakan pemberhentian presiden tersebut akan dikatakan sebagai upaya luar biasa untuk menerobos karakter fixed-term dalam sistem pemerintahan presidensial.

\section{a. Alasan-Alasan Pemberhentian Presiden}

Alasan-alasan yang dapat dipergunakan untuk memberhentikan presiden dalam masa jabatan setelah perubahan Undang-Undang Dasar Republik Indonesia Tahun 1945 yaitu sebagai berikut :

1) Pengkhianatan tehadap negara

Salah satu alasan pemberhentian presiden dalam masa jabatannya adalah telah terbukti melakukan tindakan pengkhianatan terhadap negara yang diatur dalam ketentuan Pasal 7A Undang-Undang Dasar Republik Indonesia Tahun 1945. Pengkhianatan terhadap negara diatur dalam Pasal 10 ayat (3) huruf a Undang-Undang Republik Indonesia Nomor 8 Tahun 2011 Tentang Perubahan Atas Undang-Undang Republik Indonesia Nomor 24 Tahun 2003 Tentang Mahkamah Konstitusi (MK), dalam ketentuan tersebut yang dimaksud dengan"pengkhianatan terhadap negara" adalah tindak pidana terhadap keamanan negara sebagaimana diatur dalam undangundang.

2) Korupsi dan Penyuapan

Dalam Undang-Undang Republik Indonesia Nomor 31 Tahun 1999 sebagaimana diubah dengan Undang-Undang Republik Indonesia Nomor 20 Tahun 2001, korupsi dirumuskan ke dalam 30 (tiga puluh) bentuk atau jenis tindak pidana korupsi. Dari ketiga puluh jenis tindak pidana korupsi tersebut, dapat dikelompokan menjadi delapan yaitu (1) tindak pidana korupsi yang terkait dengan kerugian keuangan negara; (2) suap 
menyuap; (3) penggelapan dalam jabatan; (4) pemerasan; (5) perbuatan curang; (6) benturan kepentingan dalam pengadaan; (7) gratifikasi dan tindak perbuatan curang; (8) pidana lain yang berkaitan dengan tindak pidana korupsi.

3) Tindak Pidana Berat lainnya

Pasal 10 ayat (3) huruf c Undang-Undang Republik Indonesia Nomor 8 Tahun 2011 Tentang Perubahan Atas Undang-Undang Republik Indonesia Nomor 24 Tahun 2003 tentang Mahkamah Konstitusi (MK) menjelaskan bahwa tindak pidana berat lainnya adalah tindak pidana yang diancam penjara 5 (lima) tahun atau lebih. Cakupannya sangat luas karena dapat meliputi semua jenis tindak pidana, sepanjang ancaman pidananya adalah penjara lima tahun atau lebih.

4) Melakukan Perbuatan Tercela

Pasal 7A Undang-Undang Dasar Republik Indonesia Tahun 1945 menyebutkan bahwa presiden dapat diberhentikan dalam masa jabatannya oleh MPR atas usul DPR, apabila terbukti telah melakukan pelanggaran hukum berupa melakukan perbuatan tercela. Selanjutnya Pasal 10 ayat (3) huruf d Undang-Undang Republik Indonesia Nomor 8 Tahun 2011 Tentang Perubahan Atas Undang-Undang Republik Indonesia Nomor 24 Tahun 2003 Tentang Mahkamah Konstitusi (MK) yang dimaksud dengan perbuatan tercela adalah perbuatan presiden yang dapat merendahkan martabat Presiden dan/atau Wakil Presiden. "perbuatan tercela" memiliki pengertian yang luas tidak hanya terbatas pada pelanggaran hukum semata-mata, akan tetapi termasuk perbuatan yang bertentangan dengan norma agama, norma kesusilaan serta norma adat.

5) Tidak Memenuhi Syarat Sebagai Presiden

Presiden tidak lagi memenuhi syarat sebagai presiden yaitu : (a) pindah kewarganegaraan lain karena kehendaknya sendiri; (b) mengkhianati negara, dan (c) tidak mampu secara rohani dan jasmani untuk melaksanakan tugas dan kewajiban sebagai presiden. 


\section{b. Mekanisme Pemberhentian Presiden}

Berdasarkan Pasal 20A ayat (1) Undang-Undang Dasar Republik Indonesia Tahun 1945 ditetapkan bahwa DPR memiliki tiga fungsi yaitu fungsi legislasi, fungsi anggaran dan fungsi pengawasan. Atas dasar pelaksanaan fungsi pengawasan, DPR dapat mengajukan usul pemberhentian Presiden kepada MPR RI, dengan terlebih dahulu mengajukan permintaan kepada Mahkamah Konstitusi. Mahkamah Konstitusi akan memeriksa, mengadili dan memutus pendapat DPR tersebut, apakah Presiden terbukti telah melakukan pelanggaran hukum atau tidak. Ketentuan tersebut diatur dalam Pasal 7B ayat (1) Undang-Undang Dasar Republik Indonesia Tahun 1945 yang menyatakan :"usul pemberhentian Presiden dan/atau Wakil Presiden dapat diajukan oleh Dewan Perwakilan Rakyat kepada Majelis Permusyawaratan Rakyat hanya dengan terlebih dahulu mengajukan permintaan kepada Mahkamah Konstitusi untuk memeriksa, mengadili dan memutus pendapat DPR bahwa Presiden dan/atau Wakil Presiden telah melakukan pelanggaran hukum berupa pengkhianatan terhadap Negara, korupsi, penyuapan, tindak pidana berat lainnya atau perbuatan tercela dan/atau pendapat bahwa Presiden dan/atau Wakil Presiden tidak lagi memenuhi syarat sebagai Presiden dan/atau Wakil Presiden.

Pengajuan pendapat DPR kepada Mahkamah Konstitusi hanya dapat dilakukan dalam Sidang Paripurna yang didukung/disetujui sekurang kurangnya $2 / 3$ dari jumlah anggota DPR dan dihadiri oleh sekurang-kurangnya $2 / 3$ dari jumlah anggota DPR sebagaimana diatur dalam Pasal 7B ayat (3) Undang-Undang Dasar Republik Indonesia Tahun 1945.

Hak menyatakan pendapat diusulkan oleh paling sedikit 25 (dua puluh lima) orang anggota DPR dan disertai dengan dokumen yang memuat paling sedikit materi dan bukti yang sah atas dugaan adanya tindakan pelanggaran atau atas dugaan tidak dipenuhinya syarat sebagai Presiden dan/atau Wakil Presiden. 
Usulan hak menyatakan pendapat menjadi hak menyatakan pendapat DPR terpenuhi, apabila mendapatkan persetujuan dari rapat paripurna DPR yang dihadiri paling sedikit 2/3 (dua per tiga) dari jumlah anggota DPR dan keputusan diambil dengan persetujuan paling sedikit 2/3 dari jumlah anggota DPR yang hadir.

Mahkamah Konstitusi wajib memeriksa, mengadili dan memutus dengan seadil-adilnya terhadap pendapat DPR tersebut paling lama 90 (sembilan puluh) hari setelah permintaan DPR itu diterima oleh Mahkamah Konstitusi.

Apabila Mahkamah Konstitusi memutuskan Presiden terbukti melakukan pelanggaran hukum dan/atau terbukti bahwa Presiden tidak lagi memenuhi syarat sebagai Presiden, maka DPR akan menyelenggarakan sidang paripurna untuk meneruskan usul pemberhentian Presiden kepada MPR. Tetapi Pasal 7B ayat (5) Undang-Undang Dasar Republik Indonesia Tahun 1945 tidak mengatur mengenai batas waktu berapa lama DPR sudah harus mengadakan sidang paripurna untuk meneruskan usul pemberhentian Presiden kepada MPR, setelah Mahkamah Konstitusi memutuskan bahwa Presiden terbukti melakukan pelanggaran hukum dan/atau terbukti tidak lagi memenuhi syarat sebagai Presiden.

Tidak adanya limitasi atau pembatasan waktu, maka DPR dapat saja mengulur-ulur waktu untuk tidak mengadakan Sidang Paripurna atau sebaliknya mempercepat pelaksanaan sidang paripurna, sangat tergantung kehendak atau kepentingan suara mayoritas anggota DPR. Dengan demikian secara yuridis tidak ada kepastian hukum perihal batas waktu penyelenggaraan sidang paripurna DPR untuk meneruskan usul pemberhentian Presiden kepada MPR.

\subsection{Pemberhentian Presiden Di Berbagai Negara}

\section{Impeachment Presiden Amerika Serikat}

Amerika Serikat (United States of Amerika) adalah sebuah republik federal yang terdiri dari 50 negara bagian dari sebuah distrik federal. Kecuali Alaska (utara Kanada) dan Hawaii (lautan pasifik), 48 
negara bagian lainnya serta distrik federalnya terletak di Amerika Utara.

Konstitusi Amerika Serikat mengatur mengenai alasan pemberhentian Presiden dan Wakil Presiden Pada Pasal 2 ayat 4 yang menyebutkan : "the President, Vice President and a all civil officers of the united states, shall be removed from the office on impeachment for and conviction of treason, Bribery, or the High Crime and Misdemeanors".

Berdasarkan ketentuan tersebut, seorang Presiden, Wakil Presiden dan seluruh Pejabat Sipil Amerika Serikat dapat diberhentikan dari jabatannya atas tuntutan, karena melakukan pengkhianatan terhadap Negara, penyuapan, melakukan tindak pidana berat serta melakukan perbuatan tercela.

Dalam praktek ketatanegaraan impeachment di Amerika Serikat, alasan pemberhentian Presiden dan/atau Wakil Presiden yang bervariasi sejak House of Representative melakukan impeachment terhadap Presiden Andrew Johnson pada tahun 1874 karena kelakuan buruk (misbehavior) yang menunjukan ketidakmampuan memegang dan melaksanakan jabatan, impeachment Presiden Nixon pada tahun 1974 dan Presiden William J. Clinton pada tahun 1998.

Berkaitan dengan prosedur atau mekanisme pemberhentian Presiden/Wakil Presiden berdasarkan konstitusi Amerika Serikat bahwa House of Representatives memiliki "the sole power of impeachment" yaitu kewenangan untuk mendakwa Presiden/Wakil Presiden dengan pasal - pasal impeachment atau dakwaan impeachment yang dimulai dengan voting mayoritas sederhana dari anggota House of Representatives dilanjutkan dengan persidangan di Senat yang memeriksa dakwaan dan memutuskan berdasarkan bukti bukti yang dihadirkan. Setiap pasal yang didakwakan diperiksa satu persatu. Akhirnya persetujuan 2/3 dari senator yang hadir menjadi prasyarat untuk removal of the President from the office atau pemakzulan Presiden. 


\section{Impeachment Presiden Filipina}

Filipina adalah sebuah Negara Republik di Asia Tenggara sebelah utara Indonesia dan Malaysia. Filipina merupakan sebuah Negara kepulauan dan negara ini terdiri dari 7.107 pulau.

Konstitusi Filipina menentukan bahwa presiden dapat dimakzulkan dari jabatannya karena dakwaan yang terbukti menyalahi konstitusi (culpable of the Constitution), pengkhianatan (treason), penyuapan (bribery), gratifikasi (graft) dan korupsi (corruption), tindak pidana berat lainnya (other high crimes) atau pengkhianatan atas kepercayaan publik (betrayal of public trust). Jika dibandingkan dengan konstitusi Amerika Serikat, pengkhianatan atas kepercayaan publik adalah alasan tambahan untuk memakzulkan Presiden Filipina.

Untuk mengajukan artikel impeachment harus didukung sekurang-kurangnya diperlukan 2/3 suara dari anggota House of Representative. Setiap anggota House of Representative harus dicatat. Selanjutnya Senat adalah lembaga negara yang memiliki kekuasaan untuk mengadili dan memutus semua perkara impeachment di Filipina. Ketika bersidang untuk tujuan itu, Senator harus bersumpah atau berjanji dan Presiden Filipina disidangkan melalui mekanisme impeachment di Senat, Ketua Mahkamah Agung akan memimpin sidang impeachment, akan tetapi Ketua Mahkamah Agung tidak memiliki hak suara. Dan tidak seorangpun, dapat dihukum tanpa persetujuan dari 2/3 anggota senat.

\section{Impeachment Presiden Republik Sudan}

Sudan (Republic of Sudan ) adalah negara yang terletak di Timur Laut benua Afrika. Sebelum referendum yang memisahkan Sudan menjadi dua bagian, Sudan merupakan Negara terluas di Afrika dan di daerah Arab, serta terluas kesepuluh di dunia. Negara ini berbatasan dengan Mesir di Utara, Laut Merah di Timur Laut, Kongo, dan Afrika Tengah di Barat Daya, Chad di Barat dan Libya di Barat Laut.

Berdasarkan ketentuan Pasal 60 ayat 2 Konstitusi Sudan Tahun 2005 disebutkan bahwa Presiden dan Wakil Presiden Republik Sudan dapat dimakzulkan (diimpeachment) karena didakwa melakukan 
pengkhianatan terhadap negara (high treason), pelanggaran berat terhadap konstitusi (gross violation of this constitutions ) dan pelanggaran jabatan (gross misconduct in relation to state affairs).

Presiden dapat dituntut (to impeach) di hadapan Mahkamah Konstitusi berdasarkan resolusi parlemen nasional yang didukung oleh 2/3 dari anggota. Selanjutnya Presiden diberhentikan dari jabatannya apabila disetujui $3 / 4$ dari anggota perlemen nasional.

\section{KESIMPULAN}

Setiap negara yang menganut sistem pemerintahan presidensial dalam konstitusinya masing- masing telah diatur mekanisme pemberhentian Presiden dalam masa jabatannya melalui instrument impeachment, baik alasan maupun prosedurnya. Tetapi yang berbeda adalah jenis sebab atau alasan impeachment nya, ada yang termasuk dalam alasan pidana (korupsi, pengkhianatan terhadap negara, tindak pidana berat, pelanggaran jabatan, perbuatan tercela dan pelanggaran Hak Asasi Manusia) dan alasan hukum tata negara (pelanggaran konstitusi, tidak mampu menjalankan kewajibannnya, melanggar kepercayaan publik) maupun alasan hukum administrasi (tidak lagi memenuhi syarat sebagai Presiden).

Secara umum prosedur pemberhentian Presiden pada negara - negara yang menganut sistem pemerintahan presidensial dilakukan oleh dua lembaga yaitu The House of Representatives sebagai lembaga yang memiliki kewenangan untuk melakukan impeachment (pendakwaan/penuntutan) dan The Senate/MPR sebagai lembaga yang berwenang untuk memakzulkan Presiden dengan atau tanpa melibatkan lembaga yudikatif, baik mahkamah Agung maupun Mahkamah Konstitusi. Seperti di Amerika Serikat dan Filipina, Ketua sidang pengadilan senat guna memakzulkan Presiden adalah Ketua Mahkamah Agung, sedangkan untuk Negara Republik Sudan dan Republik Indonesia melibatkan Mahkamah Konstitusi dalam pemberhentian Presidennya. 


\section{DAFTAR PUSTAKA}

Asshiddiqie. Jimly, 2008, Pokok-Pokok Hukum Tata Negara Indonesia Pasca Reformasi, Jakarta. Bhuana IImu Populer.

Hufron, 2018, Pemberhentian Presiden di Indonesia antara Teori dan Praktik, Yogyakarta, LaksBang Pressindo.

Isra. Saldi, 2010, Pergeseran Fungsi Kekuasaan Legislasi Menguatnya Model Legislasi Parlementer Dalam Sistem Presidensial Indonesia, PT. Raja Grafindo Persada, Jakarta.

Mahfud MD, 2007, Perdebatan Hukum Tata Negara Pasca Amandemen Konstitusi, Jakarta, LP3ES.

Nazriyah. Riri, 2007, MPR RI Kajian terhadap Produk Hukum dan Prospek Di Masa Depan, Yogyakarta, FH UII Press, Cetakan Pertama.

Sumbu. Telly dkk, 2010, Kamus Umum, Politik dan Hukum, Permata Aksara, Jakarta.

Zoelva. Hamdan, 2005, Impeachment Presiden, Alasan Tindak Pidana Pemberhentian Presiden Menurut UUD 1945, Jakarta, Konstitusi Press. 